\title{
Experimental Investigation and Formulation of Model of Deburring Process of Mat Manufacturing
}

\author{
Prajitsen G. Damle ${ }^{1 *}$, Dr. V. P. Wani ${ }^{2}$, Dr. I. D. Patil ${ }^{3}$, Dr. A. M. Nikalje ${ }^{4}$ \\ ${ }^{I}$ Department of Mechanical Engineering, SSBT's COET, Research Scholar, North Maharashtra University, \\ Jalgaon, India \\ ${ }^{2}$ Principal, MET's Institute of Engineering, Nasik, India \\ ${ }^{3}$ Professor, Department of Bio-Tech, SSBT's COET, Jalgaon, Jalgaon, India \\ ${ }^{4}$ Professor, Department of Mechanical Engineering, Govt. College of Engineering, Jalgaon, India
}

\begin{abstract}
The aim of the work was to increase the productivity of workers. The various independent parameters like BMI, Buttock-Knee length, Popliteal Height, Seat base height, back rest support height, and room temperature during deburring process of mat was investigated and also finds out influence parameter on productivity of worker. Considering these parameters the two important aspects to be considered are productivity of human workers along with the comforts to the workers.

We would like to find out which parameter is most important for increasing the productivity. The focus of this paper is to develop a Multivariable Linear Regression and Artificial Neural Network models which will predict the experimental evidences accurately. It was observed that the ANN model predict the productivity with correlation coefficient (R) 0.9412. The prediction Mean Square Error was between the desired outputs as measured values and the simulated values were obtained as 0.5009 by the model.
\end{abstract}

Keywords: Productivity, RULA, Design of Experimentation, ANOVA, Multivariable Linea Equation, Artificial Neural Network.

\section{INTRODUCTION}

From the Ergonomic check points, a well designed workstation is an important for productive work. Each workstation should be designed to match the needs of the individual worker (dependent of height, reach, size, etc) and take the type of machine being used and the task being performed into account [1]. Ergonomics is concerned with making the workplace as efficient, safe and comfortable as possible. Effective application of ergonomics in workstation design can achieve a balance between worker and task demands. This can enhance operator productivity, provide worker safety and physical and mental well-being and job satisfaction. Many research studies have shown positive effects of applying ergonomic principles in workplace design; machine and tool design, environment and facilities design [2]. Seating comfort is strongly connected with the postural support features of the seat. It is desirable and controlled seated posture. Lumber support can reduce load on the spine. Anderson et.al. research demonstrated that lumber support could reduce intradiscal on the lumbar spine. Back support is another postural support feature. Hedge and Ruder found that sitting with a backrest in a free-float mode improved the users' back support as they worked on the computer [3]. Mat manufacturing industries are small scale industries. There are no proper facilities in these companies. Deburring process is one of the operations in mat manufacturing. Debuerring is doing by female worker manually. It is a repetitive task. Though it is simple process but it performs on ground floor in sitting position on hard surface without back support.

Awkward, extreme and repetitive postures have been associated with work related musculoskeletal disorders and injury to the lower back of workers [6]. It is necessary to correlate quantitatively various dependent and independent involved in this man machine system. This correlation is nothing but a mathematical model as a design tool based on components of such workstation. Model formulation can be based on experimental data and ANN model using MATLAB.

The present study has the following goals;

1. To investigate independent and dependent parameters

2. To develop a model base on mathematical relation and on artificial neural network (ANN).

\section{MATERIALS AND METHODS}

The present study consist of two phase,

1. A cross-sectional observational type of survey was conducted in 20 Mat Manufacturing Industry in Jalgaon MIDC, Maharashtra State. In those industries a population (48 women workers) based study was designed to assess body posture. The working postures was long sitting with 
folded knees without backrest and erect back as well as bending neck. In this work station women workers are wound the cloths on Thumb, Index and Middle fingers of right hand. Sharpe and very thin blade is hold by pinch grip (A grasp in which one presses the thumb against the fingers of the hand and does not involve the palm). Required data on personal details and musculoskeletal problems was collected using DMQ (Dutch Musculoskeletal Questionnaire) and personal interview [18].

Job analysis indicates that deburring operations is the most monotonous work. Bottle neck was developing at this work station. In this task, working posture was assessed by the RULA technique [8].This was carried out with the help of digital photography. From RULA assessment sheet, grand score was '07'. It shows immediate investigation and changes are required.

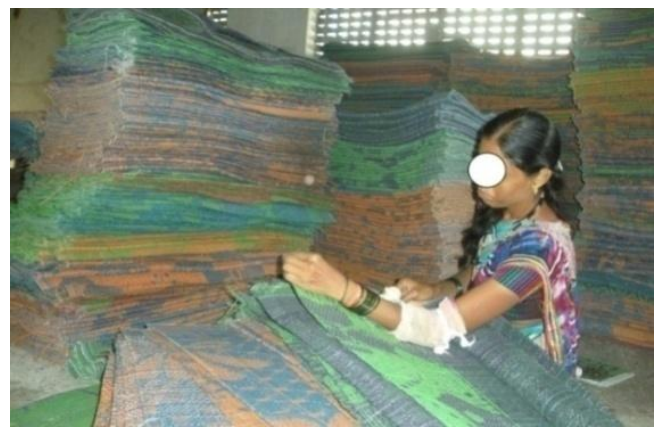

Figure 1: A typical existing working posture adapted in order to perform de-burring operation

2. It must be accepted that the point of departure in the workstation design process is that a certain production goal has to be achieved. Recommendations for workstation design must be based on a relevant set of demands. It should be noted that it is in general not enough to take into account threshold limit values for individual variables. A recognized combined goal of productivity and conservation of health makes it necessary to be more ambitious than in a traditional design situation. In particular, the question of musculoskeletal complaints is a major aspect in many industrial situations, although this category of problems is by no means limited to the industrial environment [913]. In order to improve productivity of workers, a work station was developed and constructed. To determine optimum specification, experimentations were conducted.

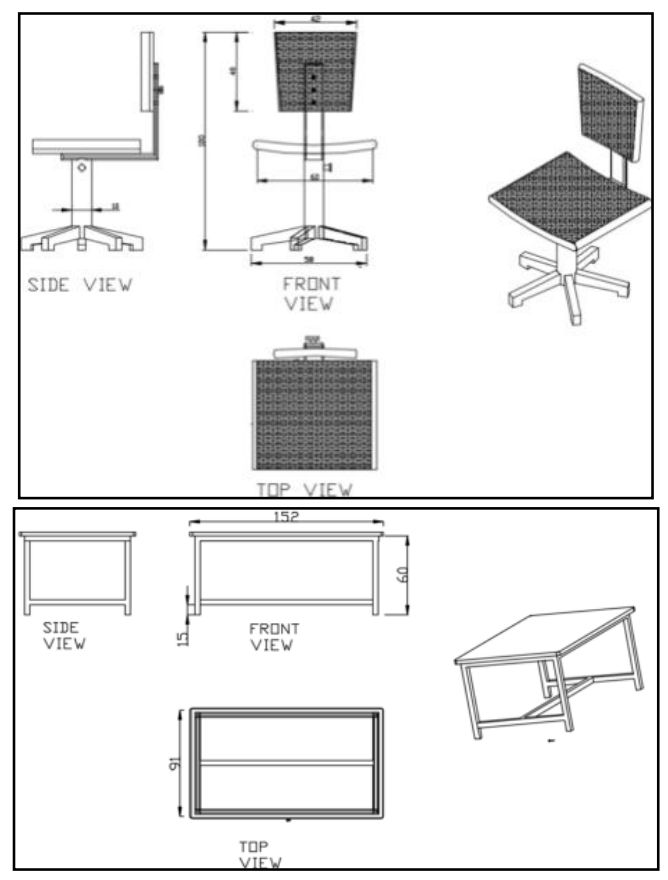

Figure 2: New workstation

To conduct experimentations, Taguchi design of experiment is used. Table 1 present the personal details of female workers.

Table 1: Personal detail of workers

\begin{tabular}{|l|c|c|c|}
\hline variables & Mean & SD & Range \\
\hline Age & 32.5 & 8.19 & $47-18$ \\
\hline Height $(\mathrm{mm})$ & 1420 & 51.65 & $1610-1420$ \\
\hline Weight $(\mathrm{Kg})$ & 32 & 15.77 & $63.2-32$ \\
\hline BMI & 21.13 & 3.80 & $28.47-13.8$ \\
\hline $\begin{array}{l}\text { Buttock-Knee } \\
\text { length }\end{array}$ & 401 & 9.91 & $419-383$ \\
\hline Popliteal Height & 545 & 25.41 & $600-490$ \\
\hline
\end{tabular}

\section{RESULTS AND DISCUSSIONS}

\subsection{Analysis from questionnaires}

From Dutch Musculoskeletal Questionnaire study on body backaches it was observed that neck and lower back pain daily occurred to $80 \%$ of the workers $\& 78.33 \%$ pain in wrist occurred.AS shown in figure 3 .

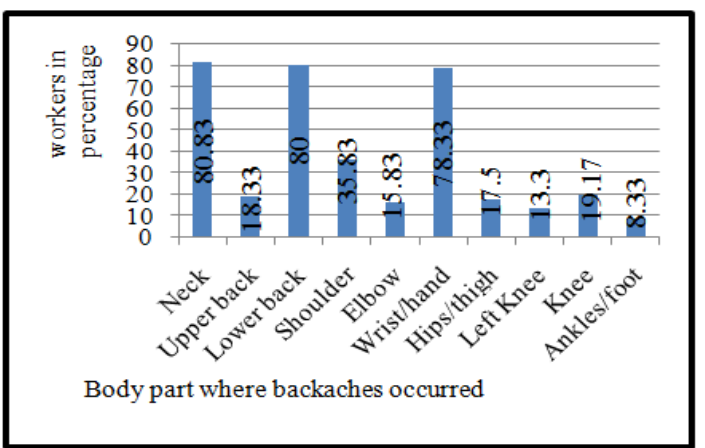

Figure 3: Bar chart of Pain in body parts 


\subsection{Analysis of Experimental Results}

This study investigates the overall effect of variables on productivity (performance i.e. output). The experiments are conducted to investigate the effect of deburring process parameters on the performance of worker i.e. output. The experiments were conducted based on Taguchi's experimental design for which an appropriate orthogonal array (OA) was selected. Productivity (performance of worker) has been evaluated for all the conditions as per $\mathrm{L}_{27}$ orthogonal array experimental design, by conducting the experiments. Effect of process parameters on Productivity (Summer Period) is shown in table 2. Percentage contribution of variable is shown in table 3 .

Table 2: $\mathrm{S} / \mathrm{N}$ ratio response table for productivity for (summer period)

\begin{tabular}{|c|c|c|c|c|c|c|}
\hline \multirow[b]{2}{*}{$\begin{array}{c}\text { Sym } \\
\text { bol }\end{array}$} & \multirow[b]{2}{*}{$\begin{array}{c}\text { Paramete } \\
\mathrm{r}\end{array}$} & \multicolumn{5}{|c|}{ Mean S/N ratio } \\
\hline & & $\begin{array}{l}\text { Lev } \\
\text { el } 1\end{array}$ & $\begin{array}{l}\text { Lev } \\
\text { el } 2\end{array}$ & $\begin{array}{l}\text { Lev } \\
\text { el } 3\end{array}$ & $\begin{array}{l}\text { Delt } \\
\text { a }\end{array}$ & $\begin{array}{l}\text { Ran } \\
\mathrm{k}\end{array}$ \\
\hline A & BMI & $\begin{array}{c}37.3 \\
7\end{array}$ & $\begin{array}{c}37.5 \\
6\end{array}$ & $\begin{array}{c}37.4 \\
1\end{array}$ & 0.20 & 5 \\
\hline B & $\begin{array}{l}\text { Buttock- } \\
\text { knee } \\
\text { length }\end{array}$ & $\begin{array}{c}37.3 \\
4\end{array}$ & $\begin{array}{c}37.5 \\
9\end{array}$ & $\begin{array}{c}37.4 \\
2\end{array}$ & 0.25 & 4 \\
\hline $\mathrm{C}$ & $\begin{array}{l}\text { Popliteal } \\
\text { height }\end{array}$ & $\begin{array}{c}37.2 \\
8\end{array}$ & $\begin{array}{c}37.4 \\
9\end{array}$ & $\begin{array}{c}37.5 \\
7\end{array}$ & 0.29 & 3 \\
\hline D & $\begin{array}{l}\text { Seat base } \\
\text { height }\end{array}$ & $\begin{array}{c}37.0 \\
0\end{array}$ & $\begin{array}{c}37.7 \\
4\end{array}$ & $\begin{array}{c}37.6 \\
0 \\
\end{array}$ & 0.73 & 1 \\
\hline E & $\begin{array}{l}\text { Back rest } \\
\text { height }\end{array}$ & $\begin{array}{c}37.3 \\
5\end{array}$ & $\begin{array}{c}37.5 \\
0\end{array}$ & $\begin{array}{c}37.4 \\
9\end{array}$ & 0.15 & 6 \\
\hline $\mathrm{F}$ & $\begin{array}{l}\text { Room } \\
\text { temperat } \\
\text { ure }\end{array}$ & $\begin{array}{c}37.4 \\
9\end{array}$ & $\begin{array}{c}37.6 \\
2\end{array}$ & $\begin{array}{c}37.2 \\
3\end{array}$ & 0.39 & 2 \\
\hline
\end{tabular}

Table 3: Result of ANOVA for (summer Period)

\begin{tabular}{|c|c|c|c|c|c|c|}
\hline $\begin{array}{c}\text { Sourc } \\
\text { e }\end{array}$ & $\begin{array}{c}\text { D } \\
\text { F }\end{array}$ & $\begin{array}{c}\text { Adj } \\
\text { SS }\end{array}$ & $\begin{array}{c}\text { Adj } \\
\text { MS }\end{array}$ & $\begin{array}{c}\text { F- } \\
\text { Valu } \\
\text { e }\end{array}$ & $\begin{array}{c}\text { P- } \\
\text { Valu } \\
\text { e }\end{array}$ & $\begin{array}{c}\text { Contribut } \\
\text { ion (\%) }\end{array}$ \\
\hline A & 2 & $\begin{array}{c}12.0 \\
7\end{array}$ & $\begin{array}{c}6.03 \\
7\end{array}$ & 0.43 & $\begin{array}{c}0.65 \\
8\end{array}$ & 3.43 \\
\hline B & 2 & $\begin{array}{c}19.1 \\
9\end{array}$ & $\begin{array}{c}9.59 \\
3\end{array}$ & 0.69 & $\begin{array}{c}0.51 \\
1\end{array}$ & 5.48 \\
\hline C & 2 & $\begin{array}{c}28.7 \\
4\end{array}$ & $\begin{array}{c}14.3 \\
7\end{array}$ & 1.07 & $\begin{array}{c}0.36 \\
0\end{array}$ & 8.26 \\
\hline D & 2 & $\begin{array}{c}195 . \\
6\end{array}$ & $\begin{array}{c}97.8 \\
1\end{array}$ & $\begin{array}{c}14.9 \\
8\end{array}$ & $\begin{array}{c}0.00 \\
0\end{array}$ & 55.52 \\
\hline E & 2 & $\begin{array}{c}9.85 \\
2\end{array}$ & $\begin{array}{c}4.96 \\
2\end{array}$ & 0.35 & $\begin{array}{c}0.71 \\
2\end{array}$ & 2.8 \\
\hline F & 2 & $\begin{array}{c}51.9 \\
3\end{array}$ & $\begin{array}{c}25.9 \\
3\end{array}$ & 2.07 & $\begin{array}{c}0.14 \\
8\end{array}$ & 14.84 \\
\hline Error & 14 & $\begin{array}{c}34.9 \\
1\end{array}$ & -- & -- & -- & 9.67 \\
\hline Total & 26 & $\begin{array}{c}352 . \\
3\end{array}$ & -- & -- & -- & 100 \\
\hline
\end{tabular}

Popliteal height, Chair Height, Backrest Support Height, Room Temp on SN ratio in summer period

In order to analyze the results, the Taguchi method uses a statistical measure of performance called signal to noise ratio ( $\mathrm{S} / \mathrm{N}$ ratio). The $\mathrm{S} / \mathrm{N}$ ratio takes the mean and the variability into account. The $\mathrm{S} / \mathrm{N}$ equation depends on the criteria for the quality characteristic to be optimized. Based on the $\mathrm{S} / \mathrm{N}$ ratio and ANOVA analysis of the result shown in table 2, figure 4 and table 3 , it is found that, the optimum level of parameters has been obtained with respective the experimental period is A2 B2 C3 D2 E2 F2. Chair base height has highest significant effect and highest contribution in performance. Whose rank is also first which has shown in $\mathrm{S} / \mathrm{N}$ ratio table 2. ANOVA result shows that, back rest height has very low significant effect and contribution in productivity. And room temperature variables has not affect on output of workers. Their significant effect and highest contribution in performance has in second level as compare to other parameter except the seat base height parameter.

\section{MODEL FORMULATION}

\subsection{Formulation of Model based on experimental} data

Experimental results are used as the training data for the multi variable linear regression (MVLR) model to map the relationship between process parameter and quality characteristics i.e. productivity. MVLRmodel has often been used to model and forecast process variables.

Regression Equation for summer season is $Y=42.6+0.021 A+0.0111 B+0.0364 C$

$$
+0.02970 D+.0122 E-0.22 F
$$

Where $Y=$ Output, $A=$ BMI, $B=$ Buttock-knee length, $C=$ Popliteal height, $D=$ Seat base height, $E$ $=$ Back rest height, $F=$ Room temperature 


\subsection{ANN Model Formulations}

Different software / tool have been developed to construct ANN. MATLAB being internationally accepted tool; has been selected for developing ANN for the complex phenomenon. In order to evaluate the performance of the developed ANN models quantitatively and verify whether there is any underlying trend in performance of ANN models, statistical analysis involving the coefficient of determination (R) and mean square error (MSE) are conducted. Graphs obtained in MATLAB software are shown in figure 5-7.

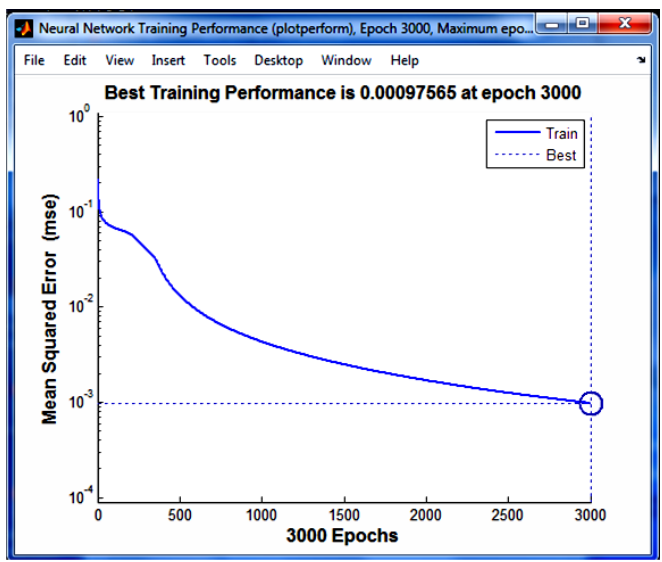

Figure 5: Performance Analysis by ANN

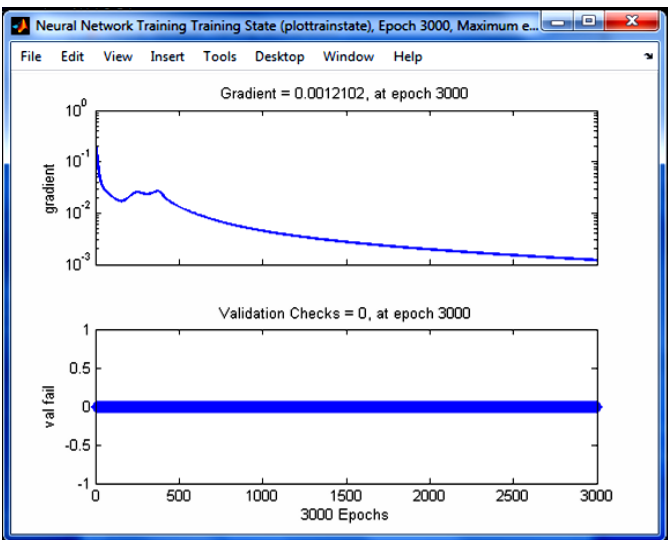

Figure 6: Training Regression Graph

\section{REFERENCES}

[1]. Hasselquist, R.J. Increasing Manufacturing Productivity Using Human Factors Principles, Proceedings of the Human Factors Society $-25^{\text {th }}$ Annual Meeting 1981.

[2]. Hedge A. and Ruder M. Dynamic sitting how much do we move when working how much do we move when working at a computer? , Proceedings of the Human Factors and Ergonomics Society $47^{\text {th }}$ Annual Meeting 2003.

[3]. Robert Norman, Richard Wells. Ergonomic Interventions For Reducing Musculoskeletal Disorders: An Overview, Related Issues And Future Directions, For The Institute For

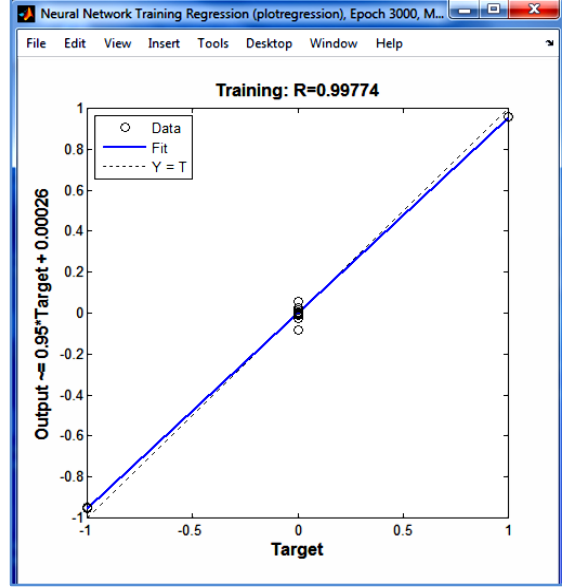

Figure 7: Validation Training graph

The best performance of network is obtain at epoch $=3000$, the gradient error is 0.0012102 . The training is $\mathrm{R}=0.99774$, there is high correlation between output and target. The training performance is 0.00097565 at epoch 3000 , the square error MSE $=$ 0.5009.The regression comparison between target and prediction vale is shown blue curve and red curve respectively.

\section{CONCLUSION}

In this paper, by using combine method of model formulation is used to compare output result of productivity. Through the establishment of set of variable, we could evaluate the performance and accuracy of the model.

A statistical method that explains how much of the variability of a factor can be caused or explained by its relationship to another factor. Coefficient of determination is used in trend analysis. It is computed as a value between 0 and 1 . Higher value better fit. Coefficient of determination is symbolized by $\mathrm{r}^{2}$ because it is square of the coefficient of correlation symbolized by $r$. The coefficient of determination is an important tool in determining the degree of linear-correlation of variables in regression analysis.

Work \& Health To The Royal Commission On Workers Compensation In British Columbia 1998.

[4]. AlirezaChoobineh*, Reza Tosian, Zahra Alhamdi, Mohammadhassan Davarzanie. Ergonomic Intervention in Carpet Mending Operation. Applied Ergonomics, vol. 35, 2004.

[5]. Nader Mahmoudi \& Majid Bazrafshan. A Carpet-Weaver's Chair Based on Anthropometric Data. International Journal of Occupational Safety and Ergonomics, Vol. 19 (4), 2013. 
[6]. Ravindra S. Goonetilleke, Song Feizhou. A methodology to determine the optimum seat depth. International Journal of Industrial Ergonomics, vol. 27, pp. 207-217, 2001.

[7]. Prajitsen G. Damle, Dr. Vijaykumar P. Wani. Productivity Improvement in MSME's Through Academic Intervention: a special reference to Mat Manufacturing Units from Jalgaon M.I.D.C. Proc. of the National Conference on Recent Trends in Mechanical Engineering 2013.

[8]. Lynn Mc Atamney, Nigel Corlett E.RULA: a survey method for the investigation of world-related upper limb Disorders. Applied Ergonomics, vol. 24 (2) 1993.

[9]. Alireza Choobineh, Mostafa Hosseini, Mohammadali Lahmi, Reza Khani Jazani, Houshang Shahnavaz. Musculoskeletal problems in Iranian hand-woven carpet industry: Guidelines for workstation design. Applied Ergonomics, vol. 38, 2007.

[10]. Jaspreet Singh, Gautam Kocher \& Harvinder Lal. Musculoskeletal Disorder among Workers in Small Scale Forging Industry. International Journal of Applied Research in Mechanical Engineering, Vol-2(2), 2012.

[11]. Michiel P. De Looze, Lottie F. M. KuijtEvers and Jaap Van Diee N. Sitting comfort and discomfort and the relationships with Journal of Current Engineering and Technology, Vol.4 (1), 2014.

[17]. S. M. Ali and N. R. Dhar. Tool Wear and Surface Roughness Prediction using an Artificial Neural Network (ANN) in Turning Steel under Minimum Quantity Lubrication (MQL). International Journal of Mechanical, Aerospace, Industrial, objective measures. ERGONOMICS, Vol. 46 (10), 2003.

[12]. A somasundaram, P S Srinivasan. Design Optimization of Dosa Making Workstation for Smooth Ergonomic Interface. Journal of Scientific and Industrial Research, Vol. 69, 2010.

[13]. Srinivas Athreya, Dr Y. D. Venkatesh .Application of Taguchi Method for Optimization of Process Parameters in Improving the Surface Roughness of Lathe Facing Operation. International Refereed Journal of Engineering and Science, Vol. 1(3), 2012.

[14]. Songbian Zime. Africa Economic Growth Forecasting Research Based on Artificial Neural Network Model: Case Study of Benin. International Journal of Engineering Research \& Technology (IJERT), Vol. 3(11), 2014.

[15]. Mark Hudson Beale, Martin T. Hagan, Howard B. Demuth. Neural network Toolbox ${ }^{\text {TM }}$ User's Guide online.2015.

[16]. Santosh Tamang A and M. Chandrasekaran. Experimental Investigation and Development of Multi Response ANN Modeling in Turning Al-SiCp MMC using Polycrystalline Diamond Tool. Internationa

Mechatronic and Manufacturing Engineering, Vol.4 (2),2010.

[18]. Veikko Louhevaara Assessment of Physical Load at Work Sites: A Finnish - German Concept. International Journal of Occupational Safety and Ergonomics, Vol.1 (2), pp.144-152. (1995). 